\title{
Exploring the relationships among
} stoichiometric coefficients, number of transferred electrons, mean oxidation number of carbons, and oxidative ratio in organic combustion reactions

\begin{abstract}
Combustion reactions, stoichiometry, and redox reactions are some of the basic contents in chemistry curriculum. Although the counting of transferred electrons is critical in redox reactions, assigning mean oxidation number of organic carbons $(\mathrm{ONc})$ is not always easy. Even though the relationship between the oxidative ratio (OR) and ONc is known, the relationship between the number of transferred electrons $\left(\mathrm{Te}^{-}\right)$and OR has not been thoroughly studied. The $\mathrm{H}$-atom method has already been developed to balance and deduct organic combustion reactions. It can be used further to help establish the relationships among the stoichiometric coefficients (SC), the number of transferred hydrogens ( $\mathrm{TH}$ ), and $\mathrm{Te}^{-}$. This article uses the procedures of the $\mathrm{H}$-atom method for balancing and deducting, and the known relationships among $\mathrm{SC}, \mathrm{TH}$, and $\mathrm{Te}^{-}$for exploring the relationships among $\mathrm{SC}, \mathrm{Te}^{-}$, $\mathrm{ONc}$, and $\mathrm{OR}$ in organic combustion reactions. By integrating three sets of relationships: (i) $\mathrm{SC}$ and $\mathrm{Te}^{-}$, (ii) $\mathrm{Te}^{-}$and $\mathrm{ON}$, and (iii) $\mathrm{SC}$ and $\mathrm{OR}$, the interconversions among $\mathrm{SC}, \mathrm{Te}^{-}$, $\mathrm{ONc}$, and $\mathrm{OR}$ can be mathematically formulated. Furthermore, $\mathrm{Te}^{-}$, ONc, and $\mathrm{OR}$ can be assigned by $\mathrm{SC}$ and the general molecular formula of $\mathrm{C}_{\mathrm{x}} \mathrm{H}_{\mathrm{y}} \mathrm{O}_{\mathrm{z}} \mathrm{X}_{\mathrm{w}}$.
\end{abstract}

Keywords: mean oxidation number of organic carbons; molecular formula; number of transferred electrons; organic combustion reaction; oxidative ratio; stoichiometric coefficients.

\section{Introduction}

Combustion reactions, stoichiometry, and redox reactions are some of the basic contents in general chemistry curriculum (Chang \& Goldsby, 2013; Tro, 2014). Redox reactions can be defined in four different models: electron transfer, $\mathrm{H}$-atom transfer, O-atom transfer, and oxidation number (IUPAC, 2019). Oxidation number is an electron-counting concept (IUPAC, 2019; Karen, McArdle \& Takats, 2014, 2016) for balancing redox reactions. It is counted by using chemical formula methods (Bentley, Franzen \& Chasteen, 2002; Halkides, 2000; Jurowski, Krzeczkowska \& Jurowska, 2015; Kauffman, 1986). Although counting oxidation number is critical for balancing organic redox reactions, assigning oxidation number of organic carbons is not always easy.

The mean oxidation number of organic carbons (or the mean oxidation state of organic carbons; ONc) is used as a redox indicator in the fields of ecosystem (Masiello, Gallagher, Randerson, Deco \& Chadwick, 2008),

\footnotetext{
*Corresponding author: Pong Kau Yuen, Department of Chemistry, Texas Southern University, Houston, TX 77004 USA, E-mail: pongkauyuen@yahoo.com. https://orcid.org/0000-0002-3045-2484

Cheng Man Diana Lau, Macau Chemical Society, Macao, Macao
}

¿ Open Access. @ 2021 Pong Kau Yuen and Cheng Man Diana Lau, published by De Gruyter. (๔) BY-NC-ND This work is licensed under the Creative Commons Attribution-NonCommercial-NoDerivatives 4.0 International License. 
environmental chemistry (Kroll et al., 2011), geochemistry (Dick \& Shock, 2011), and water biochemical treatment (Li et al., 2018).

Oxidative ratio (OR) is a reaction-based parameter which is defined by the ratio of the number of moles of $\mathrm{O}_{2}$ to one mole of $\mathrm{CO}_{2}$ in a chemical reaction (Hockaday et al., 2015; Worrall, Clay, Masiello \& Mynheer, 2013). The relationship between OR and ONc has already been known (Hockaday et al., 2015; Masiello et al., 2008; Worrall, Clay, Masiello \& Mynheer, 2013). OR is a macroscopic concept which can be determined by the stoichiometric coefficients (SC) of an overall balanced combustion equation. ONc is a microscopic concept which can be used for counting the number of transferred electrons $\left(\mathrm{Te}^{-}\right)$. Although an organic combustion reaction is an electron transfer reaction, the relationships among $\mathrm{Te}^{-}$, ONc, and OR have not been revealed. The $\mathrm{H}$-atom method (Yuen \& Lau, 2021) has been developed to balance and deduct organic combustion reactions, and has also been used to establish the relationships among SC, the number of transferred hydrogens (TH), and $\mathrm{Te}^{-}$in organic combustion reactions. This article applies the procedures of the $\mathrm{H}$-atom method for balancing and deducting, and the known relationships among SC, $\mathrm{TH}$ and $\mathrm{Te}^{-}$for exploring the relationships among the $\mathrm{SC}, \mathrm{Te}^{-}$, ONc, and $\mathrm{OR}$ in organic combustion reactions. An organic compound containing the general chemical formula of $\mathrm{C}_{\mathrm{x}} \mathrm{H}_{\mathrm{y}} \mathrm{O}_{\mathrm{z}} \mathrm{X}_{\mathrm{w}}$ is chosen as an exemplar.

By integrating three sets of relationships: (i) $\mathrm{SC}$ and $\mathrm{Te}^{-}$, (ii) $\mathrm{Te}^{-}$and ONc in a half combustion reaction, and (iii) $\mathrm{SC}$ and $\mathrm{OR}$ in an overall combustion reaction, the interconversions among these four parameters can be demonstrated by using the $\mathrm{H}$-atom method.

\section{Assigning $\mathrm{Te}^{-}$and $\mathrm{ONc}$ in a half combustion reaction}

By using the organic compound, $\mathrm{CCl}_{3} \mathrm{COOH}$, which contains halogen and oxygen atoms, as an example, the $\mathrm{H}$-atom method shows how $\mathrm{Te}^{-}$is counted. Then ONc is assigned by the derived mathematical formula.

Example 1: Balancing a half combustion reaction of $\mathrm{CCl}_{3} \mathrm{COOH}$.

$\mathrm{C}_{2} \mathrm{HO}_{2} \mathrm{Cl}_{3} \rightarrow \mathrm{CO}_{2}+\mathrm{HCl}$

$\mathrm{C}_{2} \mathrm{HO}_{2} \mathrm{Cl}_{3} \rightarrow 2 \mathrm{CO}_{2}+3 \mathrm{HCl}$

$\mathrm{C}_{2} \mathrm{HO}_{2} \mathrm{Cl}_{3}+2 \mathrm{H}+2 \mathrm{O} \rightarrow 2 \mathrm{CO}_{2}+3 \mathrm{HCl}$

$\mathrm{C}_{2} \mathrm{HO}_{2} \mathrm{Cl}_{3}+2 \mathrm{H}+2 \mathrm{O}+2 \mathrm{H} \rightarrow 2 \mathrm{CO}_{2}+3 \mathrm{HCl}+2 \mathrm{H}$

$\mathrm{C}_{2} \mathrm{HO}_{2} \mathrm{Cl}_{3}+2 \mathrm{H}_{2} \mathrm{O} \rightarrow 2 \mathrm{CO}_{2}+3 \mathrm{HCl}+2 \mathrm{H}$

The above balanced half reaction shows that there are two carbon atoms $(\mathrm{nc}=2)$ involved in the oxidation reaction. That means there is either a loss of two $\mathrm{H}$ atoms $(\mathrm{TH}=+2)$ or a loss of two protons and two electrons $\left(2 \mathrm{H} \rightarrow 2 \mathrm{H}^{+}+2 \mathrm{e}^{-} ; \mathrm{Te}^{-}=+2\right)$.

The relationship between the change of mean oxidation number of organic carbons $(\triangle \mathrm{ONc})$ and $\mathrm{Te}^{-}$is established in a half redox reaction (Yuen \& Lau, 2022). Then by deducting the mathematical equations, ONc can be assigned by $\mathrm{Te}^{-}$.

$$
\begin{gathered}
\mathrm{Te}^{-}=\mathrm{nc} \Delta \mathrm{ONc} \\
\Delta \mathrm{ONc}=\mathrm{ONc}\left(\mathrm{CO}_{2}\right)-\mathrm{ONc}\left(\mathrm{C}_{2} \mathrm{HO}_{2} \mathrm{Cl}_{3}\right) \\
\mathrm{ONc}\left(\mathrm{C}_{2} \mathrm{HO}_{2} \mathrm{Cl}_{3}\right)=\mathrm{ONc}\left(\mathrm{CO}_{2}\right)-\frac{\mathrm{Te}^{-}}{\mathrm{nc}} \\
\mathrm{ONc}\left(\mathrm{CO}_{2}\right)=+4 ; \mathrm{Te}^{-}=+2 ; \mathrm{nc}=2
\end{gathered}
$$




$$
\begin{aligned}
\mathrm{ONc}\left(\mathrm{C}_{2} \mathrm{HO}_{2} \mathrm{Cl}_{3}\right) & =\mathrm{ONc}\left(\mathrm{CO}_{2}\right)-\frac{\mathrm{Te}^{-}}{\mathrm{nc}} \\
& =4-\frac{(+2)}{2} \\
& =+3
\end{aligned}
$$

The calculated ONc of $\mathrm{C}_{2} \mathrm{HO}_{2} \mathrm{Cl}_{3}$ is equal to +3 .

\section{Counting $O R$ in an overall combustion reaction}

The H-atom method can balance an overall organic combustion reaction and consequently count OR.

Example 2: Balancing an overall organic combustion reaction of " $\mathrm{C}_{2} \mathrm{HO}_{2} \mathrm{Cl}_{3}+\mathrm{O}_{2} \rightarrow \mathrm{CO}_{2}+\mathrm{H}_{2} \mathrm{O}+\mathrm{HCl}$ ".

\begin{tabular}{ll}
\hline Step 1. & $\mathrm{C}_{2} \mathrm{HO}_{2} \mathrm{Cl}_{3} \rightarrow \mathrm{CO}_{2}+\mathrm{HCl}$ \\
& $\mathrm{O}_{2} \rightarrow \mathrm{H}_{2} \mathrm{O}$ \\
Step 2. & $\mathrm{C}_{2} \mathrm{HO}_{2} \mathrm{Cl}_{3}+2 \mathrm{H}_{2} \mathrm{O} \rightarrow 2 \mathrm{CO}_{2}+3 \mathrm{HCl}+2 \mathrm{H}$ (from Example 1) \\
& $\mathrm{O}_{2}+4 \mathrm{H} \rightarrow 2 \mathrm{H}_{2} \mathrm{O}$ \\
Step 3. & $\left(\mathrm{C}_{2} \mathrm{HO}_{2} \mathrm{Cl}_{3}+2 \mathrm{H}_{2} \mathrm{O} \rightarrow 2 \mathrm{CO}_{2}+3 \mathrm{HCl}+2 \mathrm{H}\right) \times 2$ \\
& $\left(\mathrm{O}_{2}+4 \mathrm{H} \rightarrow 2 \mathrm{H}_{2} \mathrm{O}\right) \times 1$ \\
Step 4. & $2 \mathrm{C}_{2} \mathrm{HO}_{2} \mathrm{Cl}_{3}+4 \mathrm{H}_{2} \mathrm{O}+\mathrm{O}_{2}+4 \mathrm{H} \rightarrow 4 \mathrm{CO}_{2}+6 \mathrm{HCl}+4 \mathrm{H}+2 \mathrm{H}_{2} \mathrm{O}$ \\
Step 5. & $2 \mathrm{C}_{2} \mathrm{HO}_{2} \mathrm{Cl}_{3}+2 \mathrm{H}_{2} \mathrm{O}+\mathrm{O}_{2} \rightarrow 4 \mathrm{CO}_{2}+6 \mathrm{HCl}$ \\
\hline
\end{tabular}

According to the above reaction, the $\mathrm{OR}$ which goes through the combustion of $\mathrm{C}_{2} \mathrm{HO}_{2} \mathrm{Cl}_{3}$ can be counted by the molar ratio of oxygen gas to carbon dioxide.

$$
\begin{aligned}
& \mathrm{nO}_{2}=1 ; \mathrm{nCO}_{2}=4 \\
& \mathrm{OR}=\frac{\mathrm{nO}_{2}}{\mathrm{nCO}_{2}} \\
&=\frac{1}{4}
\end{aligned}
$$

\section{Deducting relationship between $\mathrm{SC}$ and $\mathrm{Te}^{-}$in a half combustion reaction}

To deduct the stoichiometric relationship between $\mathrm{SC}$ and $\mathrm{Te}^{-}$in a half oxidation combustion reaction, a general molecular formula of $\mathrm{C}_{\mathrm{x}} \mathrm{H}_{\mathrm{y}} \mathrm{O}_{\mathrm{z}} \mathrm{X}_{\mathrm{w}}$ is chosen to demonstrate the operating procedures.

Example 3: Given $\mathrm{C}_{\mathrm{x}} \mathrm{H}_{\mathrm{y}} \mathrm{O}_{\mathrm{z}} \mathrm{X}_{\mathrm{w}} \rightarrow \mathrm{CO}_{2}+\mathrm{HX}$.

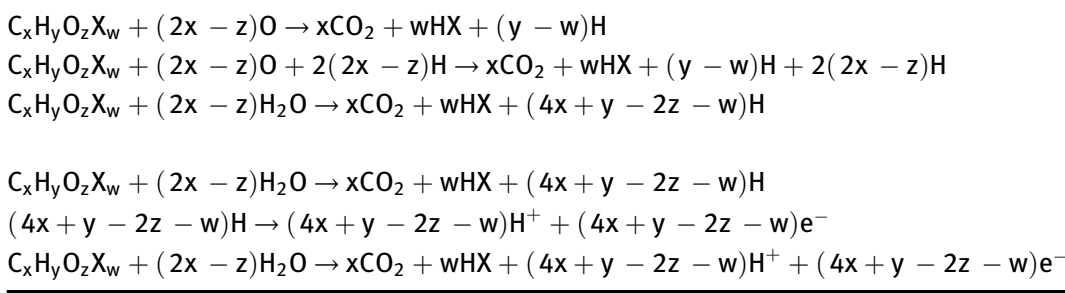


Regarding $\mathrm{C}_{\mathrm{x}} \mathrm{H}_{\mathrm{y}} \mathrm{O}_{\mathrm{z}} \mathrm{X}_{\mathrm{w}}$, the $\mathrm{x}$ number of carbons $(\mathrm{nc}=\mathrm{x})$ has participated. $\mathrm{TH}$ is equal to $\mathrm{Te}^{-}\left(\mathrm{TH}=\mathrm{Te}^{-}\right)$and $\mathrm{Te}^{-}$ are lost $\left(\mathrm{Te}^{-}>0\right)$ in the half oxidation reaction.

$$
\begin{aligned}
& \mathrm{TH}=4 \mathrm{x}+\mathrm{y}-2 \mathrm{z}-\mathrm{w} \\
& \mathrm{Te}^{-}=4 \mathrm{x}+\mathrm{y}-2 \mathrm{z}-\mathrm{w}
\end{aligned}
$$

\section{Deriving relationships among $\mathrm{SC}, \mathrm{Te}^{-}$, and $\mathrm{ONc}$}

According to the relationship between $\mathrm{SC}$ and $\mathrm{Te}^{-}$, to complement the mathematical equation of $\mathrm{Te}^{-}=\mathrm{nc} \Delta \mathrm{ONc}$, the relationship between $\mathrm{SC}$ and $\mathrm{ONc}$ of $\mathrm{C}_{\mathrm{x}} \mathrm{H}_{\mathrm{y}} \mathrm{O}_{\mathrm{z}} \mathrm{X}_{\mathrm{w}}$ is shown. The triangular relationships among $\mathrm{SC}, \mathrm{Te}^{-}$, and ONc are established in a half redox reaction and exhibited in Figure 1.

$$
\begin{gathered}
\mathrm{Te}^{-}=\mathrm{nc} \Delta \mathrm{ONc} \\
\Delta \mathrm{ONc}=\frac{\mathrm{Te}^{-}}{\mathrm{nc}} \\
\Delta \mathrm{ONc}=\mathrm{ONc} \text { (product })-\mathrm{ONc} \text { (reactant) }
\end{gathered}
$$

For the balanced half oxidation reaction:

$$
\begin{aligned}
& \mathrm{C}_{\mathrm{x}} \mathrm{H}_{\mathrm{y}} \mathrm{O}_{\mathrm{z}} \mathrm{X}_{\mathrm{w}}+(2 \mathrm{x}-\mathrm{z}) \mathrm{H}_{2} \mathrm{O} \rightarrow \mathrm{xCO}_{2}+\mathrm{wHX}+(4 \mathrm{x}+\mathrm{y}-2 \mathrm{z}-\mathrm{w}) \mathrm{H} \\
& \mathrm{Te}^{-}=(4 \mathrm{x}+\mathrm{y}-2 \mathrm{z}-\mathrm{w}) ; \mathrm{nc}=\mathrm{x} \\
& \Delta \mathrm{ONc}=\frac{\mathrm{Te}^{-}}{\mathrm{nc}} \\
& \Delta \mathrm{ONc}=\frac{4 \mathrm{x}+\mathrm{y}-2 \mathrm{z}-\mathrm{w}}{\mathrm{x}} \\
& \Delta \mathrm{ONc}=\mathrm{ONc}(\text { product })-\mathrm{ONc}(\text { reactant }) \\
& \Delta \mathrm{ONc}=\mathrm{ONc}\left(\mathrm{CO}_{2}\right)-\mathrm{ONc}\left(\mathrm{C}_{\mathrm{x}} \mathrm{H}_{\mathrm{y}} \mathrm{O}_{\mathrm{z}} \mathrm{X}_{\mathrm{w}}\right) \\
& \mathrm{ONc}\left(\mathrm{C}_{\mathrm{x}} \mathrm{H}_{\mathrm{y}} \mathrm{O}_{\mathrm{z}} \mathrm{X}_{\mathrm{w}}\right)=\mathrm{ONc}\left(\mathrm{CO}_{2}\right)-\Delta \mathrm{ONc}
\end{aligned}
$$

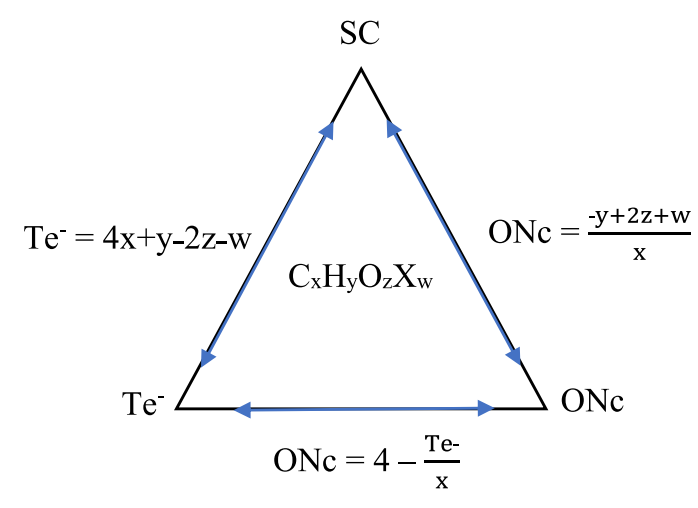

Figure 1: Triangular relationships among $\mathrm{SC}, \mathrm{Te}^{-}$, and $\mathrm{ONC}$ in a half redox reaction. 


$$
\begin{aligned}
\operatorname{ONc}\left(\mathrm{C}_{\mathrm{x}} \mathrm{H}_{\mathrm{y}} \mathrm{O}_{\mathrm{z}} \mathrm{X}_{\mathrm{w}}\right) & =\mathrm{ONc}\left(\mathrm{CO}_{2}\right)-\frac{\mathrm{Te}^{-}}{\mathrm{nc}} \\
& =4-\frac{\mathrm{Te}^{-}}{\mathrm{x}} \\
& =4-\frac{4 \mathrm{x}+\mathrm{y}-2 \mathrm{z}-\mathrm{w}}{\mathrm{x}} \\
& =\frac{-\mathrm{y}+2 \mathrm{z}+\mathrm{w}}{\mathrm{x}}
\end{aligned}
$$

\section{Deriving relationships among SC, $\mathrm{OR}$, and $\mathrm{ONc}$}

The stoichiometric relationship between $\mathrm{SC}$ and $\mathrm{ONc}$ of $\mathrm{C}_{\mathrm{x}} \mathrm{H}_{\mathrm{y}} \mathrm{O}_{\mathrm{z}} \mathrm{X}_{\mathrm{w}}$ is deducted by balancing two half reactions. Then the stoichiometric relationship between SC and OR is derived by the balancing overall combustion.

$$
\begin{gathered}
\mathrm{nO}_{2}=\frac{4 \mathrm{x}+\mathrm{y}-2 \mathrm{z}-\mathrm{w}}{4} ; \mathrm{nCO}_{2}=\mathrm{nc}=\mathrm{x} \\
\mathrm{OR}=\frac{\mathrm{nO}_{2}}{\mathrm{nCO}_{2}} \\
=\frac{4 \mathrm{x}+\mathrm{y}-2 \mathrm{z}-\mathrm{w}}{4 \mathrm{x}}
\end{gathered}
$$

Example 4: Given $\mathrm{C}_{\mathrm{x}} \mathrm{H}_{\mathrm{y}} \mathrm{O}_{\mathrm{z}} \mathrm{X}_{\mathrm{w}}+\mathrm{O}_{2} \rightarrow \mathrm{CO}_{2}+\mathrm{H}_{2} \mathrm{O}+\mathrm{HX}$.

Step 1.

Step 2.

Step 3.

Step 4.

Step 5.

$$
\begin{aligned}
& \mathrm{C}_{\mathrm{x}} \mathrm{H}_{\mathrm{y}} \mathrm{O}_{\mathrm{z}} \mathrm{X}_{\mathrm{w}} \rightarrow \mathrm{CO}_{2}+\mathrm{HX} \\
& \mathrm{O}_{2} \rightarrow \mathrm{H}_{2} \mathrm{O} \\
& \mathrm{C}_{\mathrm{x}} \mathrm{H}_{\mathrm{y}} \mathrm{O}_{\mathrm{z}} \mathrm{X}_{\mathrm{w}}+(2 \mathrm{x}-\mathrm{z}) \mathrm{H}_{2} \mathrm{O} \rightarrow \mathrm{xCO} \mathrm{CO}_{2}+\mathrm{wHX}+(4 \mathrm{x}+\mathrm{y}-2 \mathrm{z}-\mathrm{w}) \mathrm{H} \text { (from Example 3) } \\
& \mathrm{O}_{2}+4 \mathrm{H} \rightarrow 2 \mathrm{H}_{2} \mathrm{O} \\
& \left(\mathrm{C}_{\mathrm{x}} \mathrm{H}_{\mathrm{y}} \mathrm{O}_{\mathrm{z}} \mathrm{X}_{\mathrm{w}}+(2 \mathrm{x}-\mathrm{z}) \mathrm{H}_{2} \mathrm{O} \rightarrow \mathrm{xCO}+\mathrm{wHX}+(4 \mathrm{x}+\mathrm{y}-2 \mathrm{z}-\mathrm{w}) \mathrm{H}\right) \times 4 \\
& \left(\mathrm{O}_{2}+4 \mathrm{H} \rightarrow 2 \mathrm{H}_{2} \mathrm{O}\right) \times(4 \mathrm{x}+\mathrm{y}-2 \mathrm{z}-\mathrm{w}) \\
& 4 \mathrm{C}_{\mathrm{x}} \mathrm{H}_{\mathrm{y}} \mathrm{O}_{\mathrm{z}} \mathrm{X}_{\mathrm{w}}+4(2 \mathrm{x}-\mathrm{z}) \mathrm{H}_{2} \mathrm{O}+(4 \mathrm{x}+\mathrm{y}-2 \mathrm{z}-\mathrm{w}) \mathrm{O}_{2}+4(4 \mathrm{x}+\mathrm{y}-2 \mathrm{z}-\mathrm{w}) \mathrm{H} \\
& \rightarrow 4 \mathrm{CO}_{2}+4 \mathrm{wHX}+4(4 \mathrm{x}+\mathrm{y}-2 \mathrm{z}-\mathrm{w}) \mathrm{H}+2(4 \mathrm{x}+\mathrm{y}-2 \mathrm{z}-\mathrm{w}) \mathrm{H}_{2} \mathrm{O} \\
& 4 \mathrm{C}_{\mathrm{x}} \mathrm{H}_{\mathrm{y}} \mathrm{O}_{\mathrm{z}} \mathrm{X}_{\mathrm{w}}+(4 \mathrm{x}+\mathrm{y}-2 \mathrm{z}-\mathrm{w}) \mathrm{O}_{2} \rightarrow 4 x \mathrm{CO}_{2}+4 \mathrm{wHX}+2(\mathrm{y}-\mathrm{w}) \mathrm{H}_{2} \mathrm{O} \\
& \mathrm{C}_{\mathrm{x}} \mathrm{H}_{\mathrm{y}} \mathrm{O}_{\mathrm{z}} \mathrm{X}_{\mathrm{w}}+\frac{4 \mathrm{x}+\mathrm{y}-2 \mathrm{z}-\mathrm{w}}{4} \mathrm{O}_{2} \rightarrow x \mathrm{xO}_{2}+\frac{\mathrm{y}-\mathrm{w}}{2} \mathrm{H}_{2} \mathrm{O}+\mathrm{wHX}
\end{aligned}
$$

Based on the relationship of $\mathrm{ONc}=\frac{-\mathrm{y}+2 \mathrm{z}+\mathrm{w}}{\mathrm{x}}$ which is derived from the balanced half reactions and $\mathrm{OR}=\frac{4 \mathrm{x}+\mathrm{y}-2 \mathrm{z}-\mathrm{w}}{4 \mathrm{x}}$ which is derived from the balanced overall reaction, the relationship of $\mathrm{OR}=1-\frac{\mathrm{ONC}}{4}$ can be derived correspondingly. The relationships among SC, OR, and ONc for $\mathrm{C}_{\mathrm{x}} \mathrm{H}_{\mathrm{y}} \mathrm{O}_{\mathrm{z}} \mathrm{X}_{\mathrm{w}}$ are shown in Figure 2.

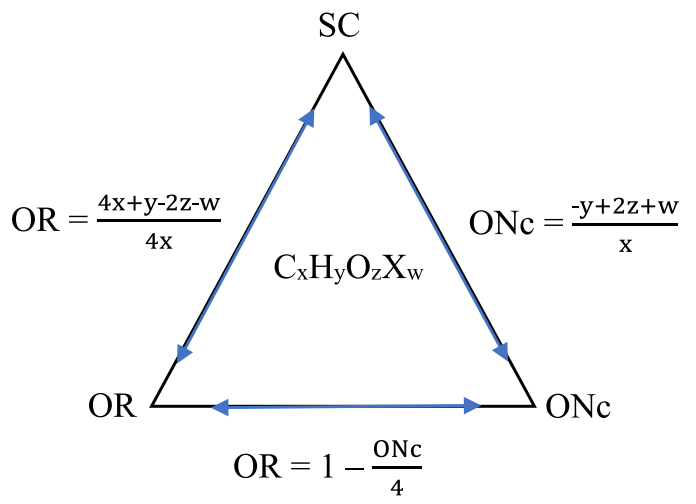

Figure 2: Triangular relationships among SC, OR, and ONc in an overall redox reaction. 


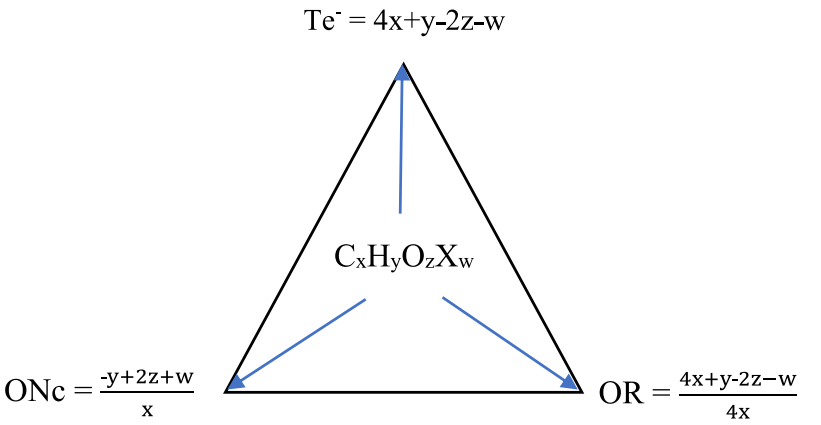

Figure 3: From molecular formula to counting $\mathrm{Te}^{-}, \mathrm{ONc}$, and OR.

\section{From molecular formula to counting $\mathrm{Te}^{-}, \mathrm{ONc}$, and $\mathrm{OR}$}

Based on the general molecular formula of $\mathrm{C}_{\mathrm{x}} \mathrm{H}_{\mathrm{y}} \mathrm{O}_{\mathrm{z}} \mathrm{X}_{\mathrm{w}}$, the relationships among $\mathrm{SC}, \mathrm{Te}^{-}$, and ONc in a half reaction and the relationships among $\mathrm{SC}, \mathrm{OR}$, and $\mathrm{ONc}$ in an overall reaction are integrated. Then the established mathematical formulas and triangular relationships are shown in Figure 3.

$\mathrm{Te}^{-}$, ONc, and OR can be assigned by SC and the given chemical formula of $\mathrm{C}_{\mathrm{x}} \mathrm{H}_{\mathrm{y}} \mathrm{O}_{\mathrm{z}} \mathrm{X}_{\mathrm{w}}$. An example is shown below.

Example 5: Determining $\mathrm{Te}^{-}$, $\mathrm{ONc}$, and $\mathrm{OR}$ of $\mathrm{CCl}_{3} \mathrm{COOH}$ in a combustion reaction.

When comparing $\mathrm{CCl}_{3} \mathrm{COOH}\left(\mathrm{C}_{2} \mathrm{HO}_{2} \mathrm{Cl}_{3}\right)$ to $\mathrm{C}_{\mathrm{x}} \mathrm{H}_{\mathrm{y}} \mathrm{O}_{\mathrm{z}} \mathrm{X}_{\mathrm{w}}, \mathrm{x}=2 ; \mathrm{y}=1 ; \mathrm{z}=2 ; \mathrm{w}=3$

\begin{tabular}{|c|c|c|}
\hline $\begin{aligned} \mathrm{Te}^{-} & =4 x+y-2 z-w \\
& =4(2)+(1)-2(2)-(3)\end{aligned}$ & $\mathrm{ONc}=\frac{-\mathrm{y}+2 \mathrm{z}+\mathrm{w}}{\mathrm{x}}$ & $O R=\frac{4 x+y-2 z-w}{4 x}$ \\
\hline$=+2$ & $=\frac{-(1)+2(2)+(3)}{2}$ & $=\frac{4(2)+(1)-2(2)-(3)}{4(2)}$ \\
\hline & $=+3$ & $=\frac{1}{4}$ \\
\hline
\end{tabular}

To determine $\mathrm{Te}^{-}$, ONc, and $\mathrm{OR}$ of the $\mathrm{CCl}_{3} \mathrm{COOH}$ compound, the $\mathrm{H}$-atom balancing equations method has been applied in Example 1 and Example 2, and the molecular formula method has been applied in Example 5. In comparison, $\mathrm{Te}^{-}$, ONc, and $\mathrm{OR}$ can be counted by a given molecular formula effectively in Example 5.

\section{Interconversions among $\mathrm{SC}, \mathrm{Te}^{-}, \mathrm{ONc}$, and $\mathrm{OR}$}

By combining the half reaction to an overall organic combustion reaction, the relationships among $\mathrm{SC}$, Te ${ }^{-}$, ONc, and OR can be derived accordingly. The interconversions are summarized in Table 1 and graphically demonstrated in Figure 4.

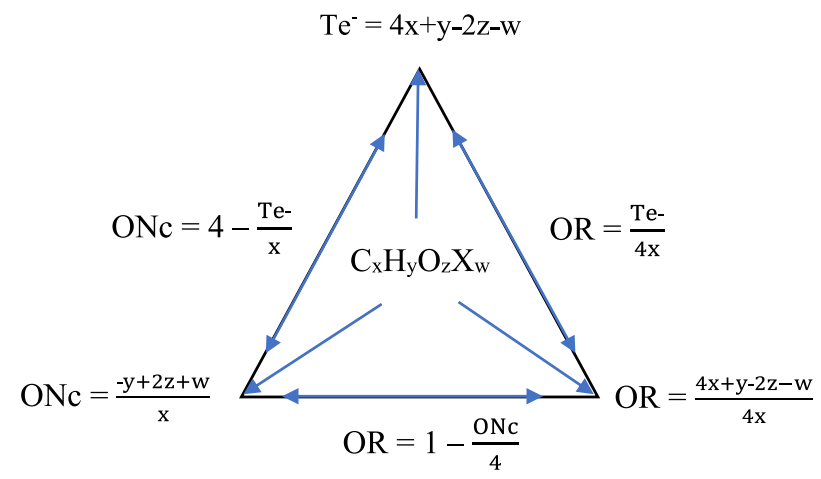

Figure 4: Interconversions among $\mathrm{SC}, \mathrm{Te}^{-}, \mathrm{ONc}$, and $\mathrm{OR}$. 
Table 1: Mathematical relationships among $\mathrm{Te}^{-}, \mathrm{ONc}$, and $\mathrm{OR}$ in organic combustion reactions.

\begin{tabular}{lll}
\hline $\mathrm{Te}^{-}$and ONc & $\mathrm{Te}^{-}$and OR & ONc and OR \\
\hline $\mathrm{nc}=\mathrm{x}$ & $\mathrm{nCO}_{2}=\mathrm{nc}=\mathrm{x}$ & $\mathrm{OR}=\frac{\mathrm{Te}^{-}}{4 \mathrm{x}}$ \\
$\mathrm{ONc}=4-\frac{\mathrm{Te}^{-}}{\mathrm{nc}}$ & $\mathrm{nO}_{2}=\frac{\mathrm{Te}^{-}}{4}$ & $\mathrm{ONc}=4-\frac{\mathrm{Te}^{-}}{\mathrm{x}}$ \\
$\mathrm{ONc}=4-\frac{\mathrm{Te}^{-}}{\mathrm{x}}$ & $\mathrm{OR}=\frac{\mathrm{nO}_{2}}{\mathrm{nCO}}$ & $\frac{\mathrm{ONc}}{4}=1-\frac{\mathrm{Te}^{-}}{4 \mathrm{x}}$ \\
$\mathrm{Te}^{-}=\mathrm{x}(4-\mathrm{ONc})$ & $\mathrm{OR}=\frac{\mathrm{Te}}{4 \mathrm{x}}$ & $\mathrm{ONc}=4(1-\mathrm{OR})$ \\
& $\mathrm{Te}^{-}=4 \mathrm{x}(\mathrm{OR})$ & $\mathrm{OR}=1-\frac{\mathrm{ONc}}{4}$ \\
\hline
\end{tabular}

Based on the given molecular formula of $\mathrm{C}_{\mathrm{x}} \mathrm{H}_{\mathrm{y}} \mathrm{O}_{\mathrm{z}} \mathrm{X}_{\mathrm{w}}$, the OR can be calculated by using SC, $\mathrm{Te}^{-}$, or ONc. Examples are shown below.

Example 6: Determining $\mathrm{Te}^{-}$, $\mathrm{ONc}$, and $\mathrm{OR}$ of $\mathrm{C}_{6} \mathrm{H}_{5} \mathrm{COCl}$ in a combustion reaction.

When comparing $\mathrm{C}_{6} \mathrm{H}_{5} \mathrm{COCl}\left(\mathrm{C}_{7} \mathrm{H}_{5} \mathrm{OCl}\right)$ to $\mathrm{C}_{\mathrm{x}} \mathrm{H}_{\mathrm{y}} \mathrm{O}_{\mathrm{z}} \mathrm{X}_{\mathrm{w}}, \mathrm{x}=7 ; \mathrm{y}=5 ; \mathrm{z}=1 ; \mathrm{w}=1$

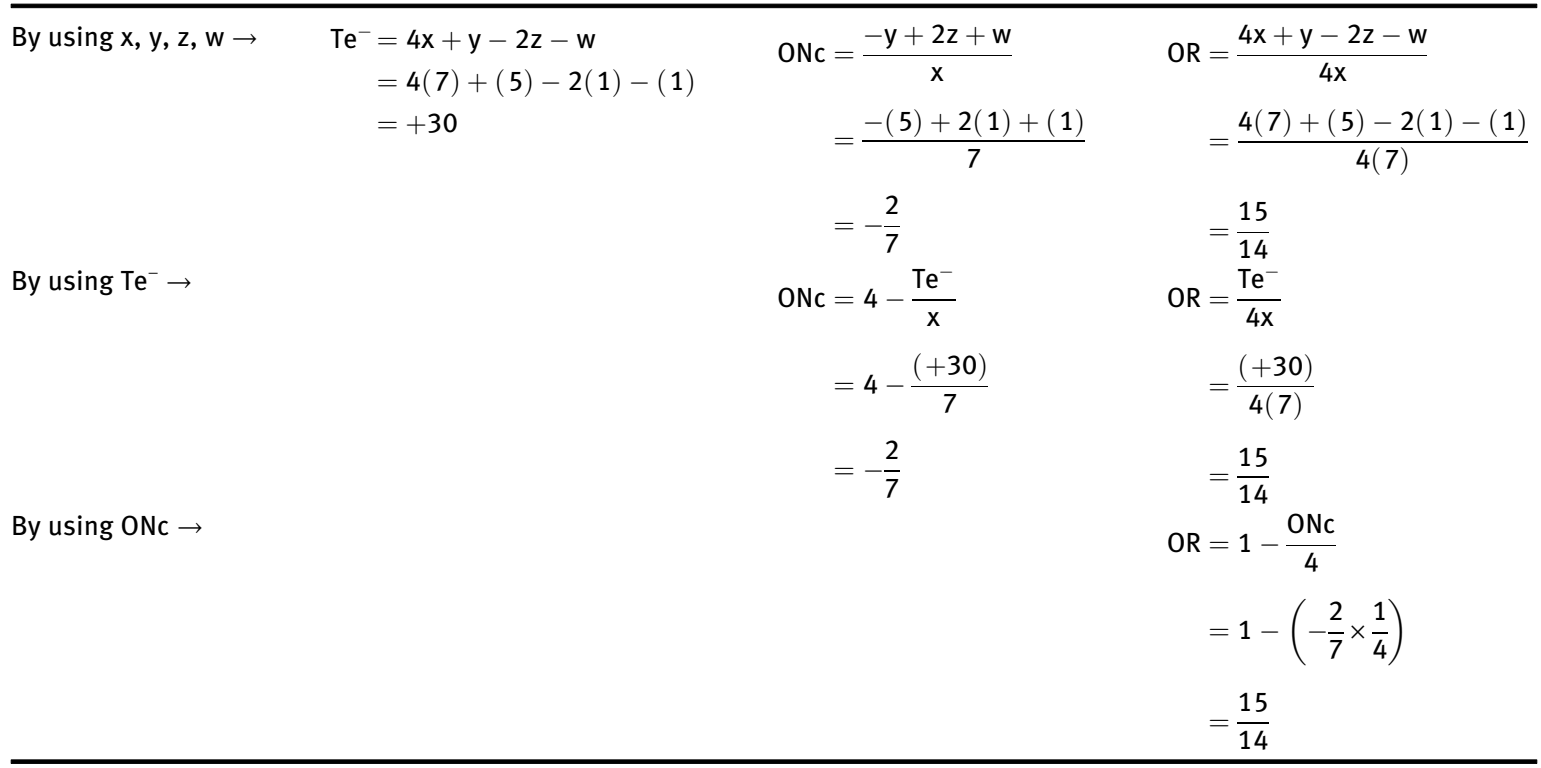

Example 7: Determining $\mathrm{Te}^{-}$, ONc, and $\mathrm{OR}$ of $\mathrm{CH}_{3} \mathrm{COOH}$ in the combustion reaction.

When comparing $\mathrm{CH}_{3} \mathrm{COOH}\left(\mathrm{C}_{2} \mathrm{H}_{4} \mathrm{O}_{2}\right)$ to $\mathrm{C}_{\mathrm{x}} \mathrm{H}_{\mathrm{y}} \mathrm{O}_{\mathrm{z}} \mathrm{X}_{\mathrm{w}}, \mathrm{x}=2 ; \mathrm{y}=4 ; \mathrm{z}=2 ; \mathrm{w}=0$

\begin{tabular}{|c|c|c|c|}
\hline \multirow[t]{2}{*}{ By using $x, y, z, w \rightarrow$} & $\begin{aligned} \mathrm{Te}^{-} & =4 \mathrm{x}+\mathrm{y}-2 \mathrm{z}-\mathrm{w} \\
& =4(2)+(4)-2(2)-(0) \\
& =+8\end{aligned}$ & $\begin{aligned} \mathrm{ONc} & =\frac{-\mathrm{y}+2 \mathrm{z}+\mathrm{w}}{\mathrm{x}} \\
& =\frac{-(4)+2(2)+(0)}{2}\end{aligned}$ & $\begin{aligned} \mathrm{OR} & =\frac{4 x+y-2 z-w}{4 x} \\
& =\frac{4(2)+(4)-2(2)-(0)}{4(2)}\end{aligned}$ \\
\hline & & $=0$ & $=1$ \\
\hline \multirow[t]{3}{*}{ By using $\mathrm{Te}^{-} \rightarrow$} & & $\mathrm{ONc}=4-\frac{\mathrm{Te}^{-}}{\mathrm{x}}$ & $\mathrm{OR}=\frac{\mathrm{Te}^{-}}{4 \mathrm{x}}$ \\
\hline & & $=4-\frac{(+8)}{2}$ & $=\frac{(+8)}{4(2)}$ \\
\hline & & $=0$ & $=1$ \\
\hline \multirow[t]{3}{*}{ By using ONc $\rightarrow$} & & & $\mathrm{OR}=1-\frac{\mathrm{ONc}}{4}$ \\
\hline & & & $=1-0$ \\
\hline & & & $=1$ \\
\hline
\end{tabular}




\section{Conclusions}

In this article, a reaction-based approach is explored to establish the relationships among $\mathrm{SC}, \mathrm{Te}^{-}, \mathrm{ONc}$, and $\mathrm{OR}$ in organic combustion reactions by using the $\mathrm{H}$-atom method. Firstly, the triangular relationships among SC, $\mathrm{Te}^{-}$, and ONc are derived in the half organic combustion reaction. Secondly, the relationships among SC, OR, and ONc are revealed in the overall organic combustion reaction. Then the interconversions among SC, ONc, $\mathrm{OR}$, and $\mathrm{Te}^{-}$are established and mathematically formulated. Furthermore, $\mathrm{Te}^{-}, \mathrm{ONc}$, and $\mathrm{OR}$ are counted by using $\mathrm{SC}$ as well as the general molecular formula of $\mathrm{C}_{\mathrm{x}} \mathrm{H}_{\mathrm{y}} \mathrm{O}_{\mathrm{z}} \mathrm{X}_{\mathrm{w}}$.

Author contributions: All the authors have accepted responsibility for the entire content of this submitted manuscript and approved submission.

Research funding: None declared.

Conflict of interest statement: The authors declare no conflicts of interest regarding this article.

\section{References}

Bentley, R., Franzen, J., \& Chasteen, T. G. (2002). Oxidation numbers in the study of metabolism. Biochemistry and Molecular Biology Education, 30, 288-292.

Chang, R., \& Goldsby, K. A. (2013). Chemistry (11th ed.). USA: McGraw-Hill International Edition.

Dick, J. M., \& Shock, E. L. (2011). Calculation of the relative chemical stabilities of proteins as a function of temperature and redox chemistry in a hot spring. PLoS One, 6(8), e22782.

Halkides, C. J. (2000). Assigning and using oxidation numbers in biochemistry lectures courses. Journal of Chemical Education, 77, $1428-1432$.

Hockaday, W. C., Gallagher, M. E., Masiello, C. A., Baldock, J. A., Iversen, C. M., \& Norby, R. J. (2015). Forest soil carbon oxidation state and oxidative ratio responses to elevated $\mathrm{CO}_{2}$. Journal of Geophysical Research: Biogeosciences, 120, 1797-1811.

IUPAC (2019). Compendium of Chemical Terminology (2nd ed.), (the "Gold Book"). Compiled by A. D. McNaught and A. Wilkinson. Oxford (1997): Blackwell Scientific Publications. Online version (2019-) created by S. J. Chalk.

Jurowski, K., Krzeczkowska, M. K., \& Jurowska, A. (2015). Approaches to determining the oxidation state of nitrogen and carbon atoms in organic compounds for high school students. Journal of Chemical Education, 92, 1645-1652.

Karen, P., McArdle, P., \& Takats, J. (2014). Toward a comprehensive definition of oxidation state (IUPAC technical report). Pure and Applied Chemistry, 86, 1017-1081.

Karen, P., McArdle, P., \& Takats, J. (2016). Comprehensive definition of oxidation state (IUPAC recommendations 2016). Pure and Applied Chemistry, 88, 831-839.

Kauffman, J. M. (1986). Simple method for determination of oxidation numbers of atoms in compounds. Journal of Chemical Education, 63, 474-475.

Kroll, J. H., Donahue, N. M., Jimenez, J. L., Kessler, S. H., Canagaratna, M. R., Wilson, K. R., .. Worsnop, D. R. (2011). Carbon oxidation state as a metric for describing the chemistry of atmospheric organic aerosol. Nature Chemistry, 3, 133-139.

Li, B., Stoddart, A. K., \& Gagnon, G. A. (2018). Mean oxidation state of organic carbon: A novel application to evaluate the extent of oxidation of natural organic matter in drinking water biological treatment. In T. L. Skovhus and B. Højris (Eds.), Microbiological Sensors for the Drinking Water Industry, IWA World Water Congress \& Exhbition 2018, Tokyo, 197-209. https://www.iwapublishing.com/sites/default/files/11_Skovhus_Ch11_R3.pdf [Accessed 1 Jul 2021].

Masiello, C. A., Gallagher, M. E., Randerson, J. T., Deco, R. M., \& Chadwick, O. A. (2008). Evaluating two experimental approaches for measuring ecosystem carbon oxidation state and oxidative ratio. Journal of Geophysical Research, 113, G03010.

Tro, N. J. (2014). Chemistry-A Molecular Approach (3rd ed.). USA: Pearson.

Worrall, F., Clay, G. D., Masiello, C. A., \& Mynheer, G. (2013). Estimating the oxidative ratio of the global terrestrial biosphere carbon. Biogeochemistry, 115, 23-32.

Yuen, P. K., \& Lau, C. M. D. (2021). Application of stoichiometric hydrogen atoms for balancing organic combustion reactions. Chemistry Teacher International, 3(3), 313-323.

Yuen, P. K., \& Lau, C. M. D. (2022). From balancing redox reactions to determining change of oxidation numbers. Journal of College Science Teaching, 51(3). 